\title{
The Development of Teaching and Learning Innovation by Using Instructional Media for Enhancement of Learning Achievement towards Tourism Product Knowledge in Tourism Marketing Class
}

\author{
Pariwat Somnuek ${ }^{1}$ \\ ${ }^{1}$ Tourism Department, Faculty of Liberal Arts, Ubon Ratchathani University, 34190 Ubon \\ Ratchathani, Thailand
}

\begin{abstract}
This study aimed to investigate (1) analyzed perspectives of the traditional teaching and the instructional media teaching to improve the tourism product knowledge in the tourism marketing class, (2) satisfaction levels, among second-year students majoring in tourism program, towards the instructional media teaching, and (3) comparative learning achievement of the students in the class. Survey questionnaires, pretest and post-test, and instructional media were applied for data collection. Furthermore, descriptive analysis and statistics such as Average, Standard Deviation, and Paired T-Test were employed of data analysis. The findings revealed that the traditional teaching employed lesser time and it was uncomplicated when applying for a class with a large number of students and several knowledge sources. However, the students played unimportant role and felt uninterested towards the lesson if the teachers were unskillful. The traditional teaching could not meet the needs and individual differences of the students while the instructional media could better develop their learning quality and their participation in learning and cognitive processes. The students' satisfaction towards the instructional media teaching was presented in the high level. Additionally, the students learning with instructional media performed the higher average test points than those learning with the traditional teaching.
\end{abstract}

\section{Introduction}

Learning media was a methodology or instrument made for learning activities in order to enhance the educational skills of learners, consistent with assigned curriculums. Traditionally, teachers were served as a source of knowledge and the media would be used by teachers for knowledge transmission to the students. However, the media could directly impose any information to learners because of its modern technology. Currently, teachers performed more significant role to be a knowledge director, who planed, selected and developed learning media effectively corresponding to their lesson contents [1].

As there were many teaching methodologies, teachers had to choose the best pattern corresponding to content and learning activities enhancing the conceptual skill of their students. The instructional media teaching served as a productive teaching for development of learning achievement. Teachers could assign some questions from a case study or a situation for students to find answers by their 
observation, perspective description, forecast, and knowledge application. Students would be more interested in learning activities since they would face direct experiences and skills [2].

Some literature reviews demonstrated that the traditional teaching was not helpful. The studies of [3-7] indicated students in traditional teaching class were assigned to mainly use memory with a plenty of educational document and books. Teachers usually employed Powerpoint presentation slides, learning documents, and description styles the students were really familiar with. Some of them did not aware to ask any questions, express opinions, and practice necessary exercises. The learning contents the teachers describe could not make them concretely understand as they could not see any case studies of real situations, experiences, problems and its possible solutions. Therefore, they were uninterested and bored resulting in low learning achievement.

Some universities tried to employ the innovative media to get rid of learning problems for sustainable learning effectiveness. Self-learning was developed in the forms of Computer-Assisted Instruction (CAI), CD Rom, and Internet Web Page, called the instructional media. The media, accompanied with motive pictures and sounds, was helpful for teacher to present the real and obvious experiences from outside the class and apply concrete knowledge to enhance students' thinking, learning, and analysis skills, leading to learning inspirations [2].

Leaning media was currently enhanced, with high-speed digital transmission on network server, as an instructional media or e-learning. Learners could control and select contents they wanted to study via a computer network. The instructional media could be modified to meet the needs of teachers and students and teaching styles could be recorded in the media to solve and develop ways of teaching [8]. Students could completely observe any matters from far visions and comprehend sequences of pictures with rapid displays that could not be perceived by human visual such as animation and multiplicity from two different sources such as scientific documentaries, live broadcasting programs, and CCTV. It could be said that the media was exactly influential in learning and teaching activities [9].

The effectiveness of the instructional media teaching depended on learning achievement in three steps. Firstly, [10] stated that there would be a pre-learning evaluation to consider both direct and indirect learning contexts such as intelligence, readiness, interests, and values of the students. Evaluation while learning was performed later to improve the learning quality such as learning behaviors, attentions, and activity participations. Then, post-learning or summative evaluation was done to measure their three achievement perspectives: cognitive, affective, and psychomotor domains. Learning achievement also included awareness, comprehension, skills, and learning attitudes teachers might measure by learning evaluations or other methodologies [11]. The achievement could indicate learning quality and competences of teachers and administrators.

The study of [12] demonstrated that the instructional media, used for learning of product mix, could effectively enhance learning achievement of the selected students and they were satisfied with the media teaching, as expected results. Thus, this researched aimed to investigate the media teaching and it can be advantageous for teachers to progress their effective teaching.

A lot of researchers tended to investigate an effectiveness of the instructional media. However, this study aimed to find both traditional teaching and the instructional media teaching used for tourism product learning in the class. An examination of students' satisfaction towards the instructional media along with comparative learning achievement of the students towards the two teaching methods was also gauged.

\section{Methodology}

To measure the satisfaction of the students, satisfactory questionnaires concerning the instructional media teaching, with five rating scales, given to a total of 60 sample students were used for data collection. The questionnaires consisted of three parts: general information, satisfactory levels, and development suggestions. The satisfactory average point was used for data analysis. Relating the teaching method, learning documents and research studies related to the traditional teaching and the instructional media teaching, and Descriptive Analysis were employed for describe the result. 
For comparative analysis of the learning achievement, the media of tourism products, included specific characteristics, product levels, marketing mix, product life cycle, marketing strategies, and tourism product development, was used. The test of [13] with 20 questions and multiple choices given to the total sample representatives, consisting of 30 of a control group and 30 of a test group, were employed for data collection. Their average scores of pre-test and post-test of the two teaching methods among were measured. Then, Paired t-test [14], Content Analysis, and Reliability [15] were employed for data analysis. This study was conducted from October 1, 2012 - September 30, 2013 in the tourism marketing class in Liberal Arts Faculty, Ubon Ratchathani University.

\section{Data Analysis and Discussion}

\subsection{Teaching Content Analysis in Both the Traditional Teaching and the Instructional Media Teaching of Tourism Product Learning in the Class}

\subsubsection{Traditional teaching}

This teaching mainly employed lecture, narration, or explanation in what the teachers wanted the students to know. Opportunities to ask questions were granted, a way for evaluation of their learning. For its benefits, this teaching was helpful for a large group of students to learn many sources of information in limited time. It was convenient for teachers as they used less time and could imposed a plenty of knowledge to their students [12]. However, Student-centered learning was not focused on, making them uninterested in the teaching. The learning achievement totally depended on teachers' competence, interesting explanation styles, and management of lesson contents. The students were not successful in learning if the teachers were inexpert and participations on asking questions were not granted. Thus, this teaching could not fulfill the needs of students and the individual differences.

\subsubsection{Instructional media teaching}

In this teaching, learning accessories, materials, instruments, and symbols were applied for imposing the expected knowledge. Complicated lesson contents would be made easier to understand, leading to more students' interest for learning several sources of knowledge. The quality of their learning would be enhanced as they could study more information in the expected time and pay more attention to participate in learning activities [16].

\subsection{The Students' Satisfaction Towards the Instructional Media Teaching}

Table 1. Satisfaction levels towards the instructional media teaching

\begin{tabular}{|c|l|c|c|}
\hline NO. & \multicolumn{1}{|c|}{ Contents } & Average & Meanings of Average \\
\hline 1 & Media contents were easy to understand & 3.79 & High level \\
\hline 2 & Media contents were consistent with the lesson & 3.71 & High level \\
\hline 3 & Media pictures were consistent with the lesson & 3.92 & High level \\
\hline 4 & Media was convenient to use & 3.83 & High level \\
\hline 5 & Media content enhanced more understanding of & 3.63 & High level \\
\hline
\end{tabular}




\begin{tabular}{|c|c|c|c|}
\hline NO. & Contents & Average & Meanings of Average \\
\hline & the lesson & & \\
\hline 6 & $\begin{array}{l}\text { Media encouraged students to research from } \\
\text { additional data sources }\end{array}$ & 3.92 & High level \\
\hline 7 & Description sounds were clear and interesting & 3.62 & High level \\
\hline 8 & $\begin{array}{l}\text { Media pictures were clear and easy to } \\
\text { understand }\end{array}$ & 3.96 & High level \\
\hline 9 & Media contents were useful for learning & 3.83 & High level \\
\hline 10 & $\begin{array}{l}\text { The overall media was interesting and } \\
\text { appropriate for learning }\end{array}$ & 3.71 & High level \\
\hline & Total & 3.79 & High level \\
\hline
\end{tabular}

From the table, the overall satisfaction of the students was presented in the high level, the average at 3.79. Considering each factor, the most average, 3.96, was the perspective of "Media pictures were clear and easy to understand" while the least average, 3.62, was "Description sounds were clear and interesting". Notwithstanding, all factors were appeared in the high level.

Most students highly satisfied with the media teaching because the media, in their opinion, was appropriate for learning and the media stored a plenty of colorful and interesting pictures [17]. The study in the class would be enjoyable and entertained, making more interests for the students. In addition, learning media used in this study was checked by specialists, leading to efficiency of the lesson learning.

\subsection{Comparative Learning Achievement of the Students Towards the Two Teaching Methods in the Class}

Table 2. Comparative learning achievement of the students towards the two teaching methods in the class

\begin{tabular}{|c|c|c|c|c|c|c|c|c|}
\hline \multirow{2}{*}{$\begin{array}{c}\text { Teaching } \\
\text { methods }\end{array}$} & \multicolumn{2}{|c|}{ Pre-test } & \multicolumn{2}{c|}{ Post-test } & \multicolumn{2}{c|}{ Pre-test, Post-test } & t & P \\
\cline { 2 - 9 } & $\overline{\mathrm{X}}$ & S.D. & $\overline{\mathrm{X}}$ & S.D. & $\overline{\mathrm{X}}$ & S.D. & $\overline{\mathrm{X}}$ & S.D. \\
\hline $\begin{array}{c}\text { Traditional } \\
\text { teaching } \\
(\mathrm{N}=30)\end{array}$ & 4.15 & 3.43 & 6.8 & 1.85 & -2.68 & 1.88 & $3.89^{* * *}$ & 0.00 \\
\hline $\begin{array}{c}\text { Instructional } \\
\text { media teaching }\end{array}$ & 8.23 & 6.86 & 13.60 & 3.70 & -5.37 & 3.77 & $-7.79^{* * *}$ & 0.00 \\
$(\mathrm{~N}=30)$ & & & & & & & & \\
\hline
\end{tabular}


In the table, it was found that the learning achievement between the pre-test and the post-test of the students, learned by the traditional teaching, was significantly different. The average scores of the post-test were found higher than the pre-test, as the same with those who learned by the instructional media. Although the two student groups held learning achievement, it was noticed that the average scores of the students learned by the media, both pre and post tests, were higher than the traditional teaching.

Some academicians pointed out that learning achievement hinged on several contexts. [18] indicated that the contexts composed of innate abilities, living and family, school efficiency, self understanding, future focus. Also, the learning achievement might rely on three significant variables: knowledge, affective domain, and teaching quality [19].

The teaching quality might be suggestions, learning objectives, learning participation, teacher cooperation, learning feedbacks, and problem solutions. [20] focused on the achievement, in primary education, derived from learning quality, educational supervision, and educational management. Significantly, these studies were consistent with [21] that the achievement contexts included the perspectives of body, love, culture, relationship, individual development, and adaptation.

As concepts and research findings previously mentioned, it might be concluded that the learning achievement comprised of three categories: students and their environment, teaching quality, and effective management of learning activities. The findings found in this study were corresponding to the study of [9] as the media teaching was helpful and influential in education. Media could present the outstanding experiences from outside the class and impose concrete knowledge to enhance students' learning skills efficiently. Furthermore, the teaching style could be recorded in the media to recheck, resolve and develop all problems of teaching.

The findings were also consistent with the study of [10] as the media could encourage the students could observe any matters from far visions and understand sequences of pictures with rapid displays that could not be perceived by human visual such as animation and multiplicity from two different sources. The media could be edited to make it up-to-date with the lesson contents. Also, media teaching was inexpensive and convenient to use.

The results regarding the students' satisfaction were consistent with the study of [22] as the satisfaction was correlated with expectations and outcomes, dividing into three levels such as unsatisfied, satisfied, and highly satisfied. These levels depended on perception, experiences, analysis, and evaluation of individuals.

The results were also complied with [23] that the working inspirations of workers resulted from an understanding of personal thinking and awareness. They would perform proficiently and work hardly if they received reasonable benefits from what they worked or held satisfied working outcomes, such as getting a promotion, higher incomes, and additional welfares. They felt that they were respected and self-esteemed from others.

Additionally, the results were corresponding to [1] studying the media use for the product mix lesson in Sakaew Community College. The findings demonstrated that the media could develop the learning achievement among the students, as expected outcomes.

Some of the teaching classes might use a combination of face to face and instructional media because of two ways communication between teachers and students. Students were asked to analyze and answer a set of questions after learning by instructional media for more comprehension of the students.

The progress of students' learning was evaluated by the learning achievement tests including pretest and post-test. In short, although the media was helpful, traditional teaching might be used, in some cases, to progress the teaching processes and an understanding of the lessons from real situations and globalized experiences. 


\section{Recommendations}

The study of comparison of other media used in the class (e.g. personal media and visual media) should be conducted. Also, the comparison of learning achievement among two student groups, who choose the tourism program as their major elective and minor elective, should be focused.

\section{Conclusion}

In this study, both teaching methods held their own advantages relying on lesson contents and objectives of teachers. Learning media served as a communication channel between teachers and students determining a mutual understand of the communication contents. If students conceived its contents, they would be assumed to have learning achievement. In this communication, teachers' expectations served as an input, media as a process, and students' satisfaction as output. Most students were highly satisfied with the instructional media teaching. The average scores of both pre-test and post-test of the students learned by the instructional media were higher than those who learned by the traditional teaching.

\section{References}

1. S. Janlekha, Development of Learning Achievement of Product Mix Study among Diploma Students in Sakaew Community College by Using Instructional Media, (2008)

2. C. Pornkul, Teaching Design, 2 (2009)

3. B. Horpetch. Learning Management of Physical Education of Grade 5 Students in Muay Thai (Thai Boxing) Class by Using Instructional Media, (2008)

4. A. Buaphan, Development of Instructional Media Uses in Basic Nursing Class Among Senior Scouts Provided for Grade 8 Students, (2008)

5. N. Kiatniyomdee, Development of Instructional Media Uses in Carpenter Accessory Class Among Grade 9 Students in Academic Year of 2008, (2008).

6. T. Panhiran, Video Compact Disc on Digital Camera Photography, (2002)

7. K. Yodchai. Karaoke Media Learning Among Fourth Year Bachelor Students on Nursing of Patients of Coronary Heart Disease, (2007)

8. V. Nualsakul, Learning Exercises in Computer-assisted Instruction Affecting Chemical Learning Achievement of Bachelor Students, (1997)

9. Arerak, et al., Knowledge Management in Several Perspective, (2004)

10. N. Atchariyakul, P. Pookhut, Image Media: Teaching Publications for the Subject of Basic Slides and Movies: Unit 14, (1999)

11. P. Rithilan, P, Educational Measurement and Evaluation, 3 (2011)

12. J.J. Eysenck, W. Arnold, R. Meili, Encyclopedia of Psychology, (1972)

13. B. Srisa-ad, Preliminary Research, 2 (1992)

14. Field, Discovering Statistics Using SPSS for Windows, (2000)

15. J. C. Nunnally, Psychometric Theory, 2 (1978)

16. P. Dechakup, P. Yindesook, Backward Design and Child-Centered, (2009)

17.P. Promhitatorn, A Study of Thai Word Spelling Competence and Use of Official Dictionary of Thai Words (2525 B.E.) Among Grade 9 Students in Academic Year of 1998: A Case Study of Department of General Education in Songkhla Province, (1999) 
18. Harvighurst, Neugarten, Society and Education, (1969)

19. Bloom, Taxonomy of Educational Objectives, the classification of educational goalsHandbook I: Cognitive Domain, (1976)

20. Office of the National Primary Education, English Program in Primary Education (2541 B.E.), (1998)

21. P. Torchoke, A Casual Relationship Study Between Characteristics of Students, Teachers, Home Environment, and Physics Learning Achievement: A Case Study of Grade 12 Students in The Secondary Education Service Area Office 11, (1995)

22. Kotler, Marketing Management: Analysis, Planning, Implementation, and Control, 9, (1997)

23. Vroom, Manage people not personnel: Motivation and performance appraisal, (1990). 